\title{
Article
}

http://dx.doi.org/10.11646/phytotaxa.265.3.7

\section{Lessingianthus concepcionis (Asteraceae, Vernonieae), a new octoploid species endemic to northern Paraguay}

\author{
MARIA BETIANA ANGULO ${ }^{1,2,}$ \& MASSIMILIANO DEMATTEIS ${ }^{1,2}$ \\ ${ }^{\prime}$ Instituto de Botánica del Nordeste (UNNE-CONICET), Casilla de Correo 209, 3400 Corrientes, Argentina. \\ ${ }^{2}$ Facultad de Ciencias Exactas y Naturales y Agrimensura, Universidad Nacional del Nordeste, Corrientes, Argentina. \\ *Author for correspondence. E-mail: angulobetiana@gmail.com
}

\begin{abstract}
Lessingianthus concepcionis, a new species from northern Paraguay is described and illustrated. The new species has a certain resemblance to $L$. niederleinii but can be easily separated by the combination of leaves with denticulate and revolute margins, tomentose beneath, involucre with 6-7 series of phyllaries, glandular trichomes on the corolla lobes, and the chromosome number $2 \mathrm{n}=8 \mathrm{x}=128$.
\end{abstract}

Keywords: new taxon, Lepidaploinae, taxonomy

\section{Introduction}

Lessingianthus Robinson (1988: 939) is a South American genus of family Asteraceae Berchtold \& Presl (1820: 254) and belongs to the tribe Vernonieae Cassini (1819: 203). The species of the genus are perennial herbs or shrubs with xylopodia, having medium or large-sized heads and seriate-cymose synflorescences (Robinson 1999). It comprises 133 species (Angulo \& Dematteis 2014a, c) distributed in South America, including Brazil, Bolivia, Paraguay, Argentina, Uruguay, Venezuela, Colombia and Peru (Robinson 2007). This group can be distinguished from the remaining American members of the tribe by a combination of characters, such as 'type B' pollen grains, base chromosome number $\mathrm{x}=16$, and several micromorphological features, such as non-glandular anther apical appendage, absence of basal stylar node (rarely present), and cubic and prismatic crystals on the fruit wall (Robinson 1999; Angulo \& Dematteis 2010, 2012a, 2014a; Angulo et al. 2015b).

Our ongoing taxonomic studies on Lessingianthus allowed us to describe several new species on the basis of the combination of "traditional" morphological characters (inflorescence type, head distribution, phyllary shape) along with micromorphological features of flowers and fruits and cytological data (Angulo \& Dematteis 2012a, b, 2014a, c, 2015, Angulo et al. 2012, 2015, Dematteis \& Angulo 2012).

Chromosome characteristics (chromosome numbers, ploidy level, karyotype formula) are highly diverse in Lessingianthus and taxonomically useful to distinguish one species from another (Ruas et al. 1991; Dematteis 1997; Angulo \& Dematteis 2012b, 2015). Polyploidy is a very common phenomenon in Vernonieae, and Lessingianthus has the greatest proportion of polyploids known within the tribe, with over $66.6 \%$ of a total of 33 taxa analyzed citologically (Ruas et al. 1991; Dematteis 1996, 1997, 1998, 2002; Dematteis et al. 2007; Oliveira et al. 2007a; Angulo \& Dematteis 2009a, b). Besides, the genus comprises species with a broad range of ploidy levels ranging from tetraploids to endecaploids, tetraploids (54.5\%) and hexaploids (22.72\%) being more or less common and octoploids (9.09\%), decaploids (9.09\%) and endecaploids (4.54\%) rare. Variations in ploidy levels (chromosome number) and morphological features were used in the revision of taxa of $L$. saltensis (Hieronymus 1897: 691) Robinson (1988: 948) complex (Angulo \& Dematteis 2012b) and L. rubricaulis (Humboldt \& Bonpland 1809: 66) Robinson (1988: 948) complex (Angulo \& Dematteis 2014b) showing the taxonomic utility of cytological data as additional characters to be distinguished among species.

Similarly, studies of micromorphological features of flowers and cypselas (trichome types, crystal types in the pericarp, style base) are also an important source of information for characterization and classification at specific 
level (Angulo \& Dematteis 2014a; Angulo et al. 2012, 2015). Here, we describe a new species from Paraguay based on morphological and micromorphological features, and chromosome number. This new species is illustrated and its affinities are discussed.

\section{Material and methods}

\section{Field study and plant collection}

Material of the new species was collected in the field. Part of this material was prepared for herbarium collection, while some fruit and flower samples were stored for cytological and micromorphological studies. Herbarium material deposited at CTES, FCQ and SI (abbreviations are according to Index Herbariorum, http://sweetgum.nybg.org/ih, accessed 10 February 2016) was studied. The terminology applied for the description of the species generally follows Robinson (1988) and Dematteis (2007). The line drawings were done under camera lucida with a Leica MZ6 stereo microscope using pressed specimens.

\section{Cytological analysis}

For cytological analysis, root tips of germinating seeds were pretreated in $0.002 \mathrm{M}$ 8-hidroxyquinoline for 4-5 h, then fixed in acetic acid: absolute alcohol (3:1) over night, and stored in 70\% aqueous ethanol. Root tips were stained according to the Feulgen's technique, and meristems were macerated and squashed in a drop of lacto-propionic orcein (Dyer 1963). Permanent microscope slides were prepared in Euparal using Bowen (1956)'s method.

\section{Micromorphological analysis}

For micromorphological analysis, florets and fruits were softened in destilled water and cleared in sodium hypochlorite: water (1:1) until the samples became transparent. Transparent samples were washed in running water and dissected under a stereomicroscope and then mounted in Hoyer's solution (Anderson 1954; King \& Robinson 1970). Samples were examined and photographed using Zeiss Axioplan microscope with digital camera Canon Power Shot A 640.

\section{Taxonomic treatment}

\section{Lessingianthus concepcionis M.B. Angulo \& Dematteis, sp. nov. (Fig. 1)}

Type:-PARAGUAY. Concepción: 1 km E de Huguá Poí [S 2312'38", W 57¹4'25"], 4 March 2009, M. Dematteis, M. Franco \& H. A. Keller 3230 (holotype CTES!, isotype FCQ!, SI!).

Diagnosis:-Differs from L. niederleinii (Hieronymus 1897: 681) Robinson (1988: 946) by its leaves with denticulate and revolute margins, tomentose beneath, and glandular trichomes on corolla lobes (versus leaves with entire or briefly serrate, never revolute margins, and glandular and non-glandular trichomes on corolla lobes).

Erect shurb, $2.5 \mathrm{~m}$ tall. Stems single, lanate, densely leafy to the inflorescence. Leaves coriaceus, sessile, 7-8 $\times$ $4.5-5 \mathrm{~cm}$. Leaf blades lanceolate, acute at apex, base attenuate, scabrous above, tomentose beneath, pinnatinervate, secondary veins prominent above, margins denticulate, revolute. Capitula numerous, sessile grouped on seriate-cymose branches. Bracts of the synflorescence leafy, lanceolate, 11-14 mm long. Involucre campanulate, 11-12 × 9-10 mm; phyllaries in 6-7 series, slightly imbricate, coriaceous, ciliate at margin, outer phyllaries linear, 3-4× 1.3-1.6 mm, subulate and recurved at the apex, middle phyllaries linear to oblong-linear, 5-6.5 $\times 1.8-1.9 \mathrm{~mm}$, subulate and slightly recurved at the apex, inner phyllaries oblong-lanceolate, 8.5-9 × 1.6-1.9 mm, acute, papillose. Florets 20-30; corolla violet, 10-12 mm long, corolla lobes with glandular trichomes. Anthers sagittate, techae 3-3.5 long, apical appendage ovate-lanceolate, $0.6 \mathrm{~mm}$ long. Styles $12.5 \mathrm{~mm}$ long, without basal stylar node. Cypselas turbinate, ribbed, laxly sericeous-pubescent, $4-4.5 \mathrm{~mm}$ long, fruit wall with cubic and prismatic crystals. Pappus biseriate, white, outer series scales lanceolate, fimbriate, $0.8-1.2 \mathrm{~mm}$ long, inner series bristles $6-7 \mathrm{~mm}$ long. $2 \mathrm{n}=128$.

Distribution and habitat:- This taxon grows in Paraguay, only known from Concepción Department. It grows in areas with calcareous soils in cerrado habitats. 


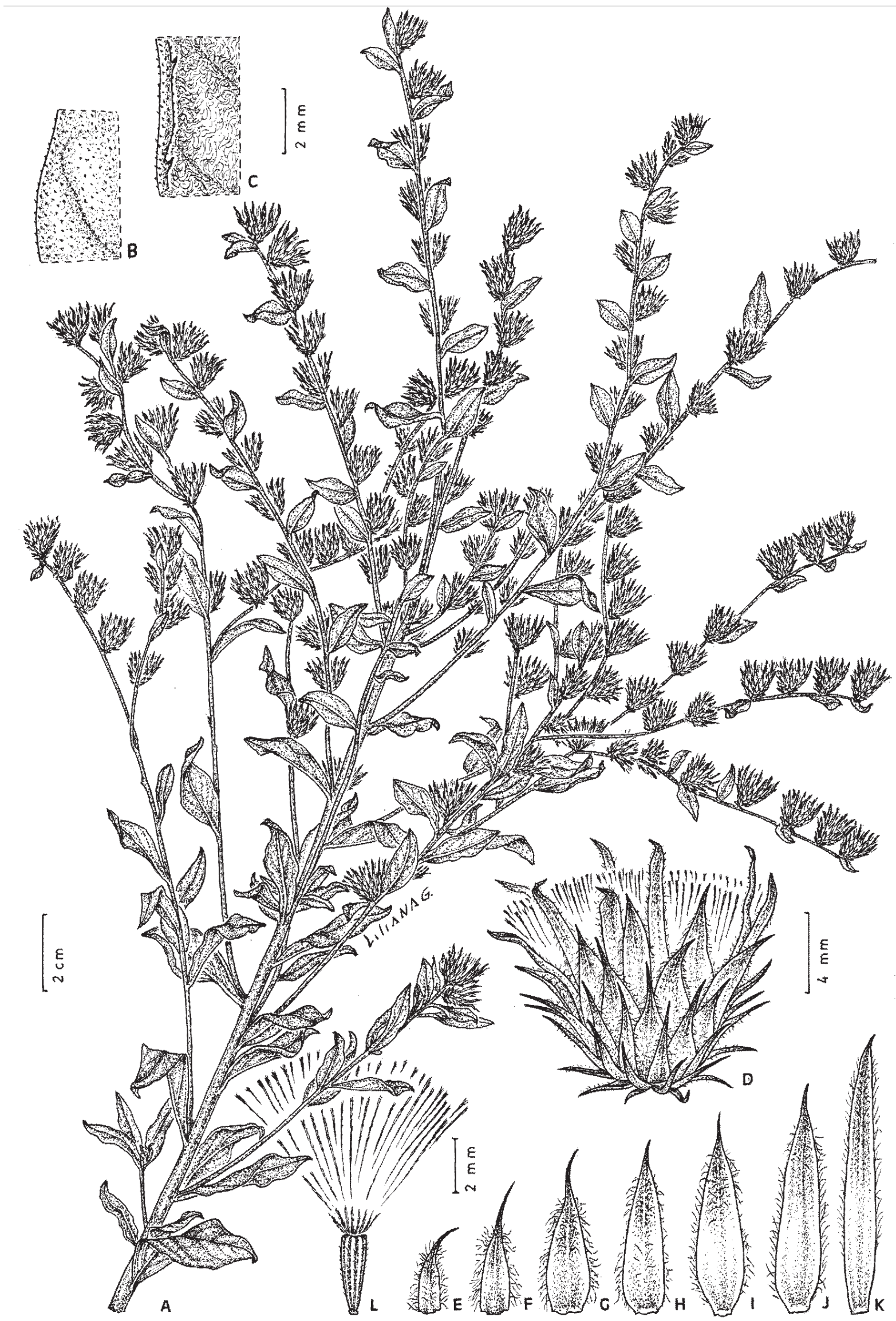

FIGURE 1. Lessingianthus concepcionis. A: Plant. B-C: Detail of leaf margin. B: adaxial surface. C: abaxial surface. D: Capitulum. E-G: Outer phyllaries. H-I: Middle phyllaries. J-K: Inner phyllaries. L: Cypsela with pappus. (A-L: from Dematteis et al. 3230 , CTES; illustrated by Mirtha L. Gómez). 
Conservation status:- Lessingianthus concepcionis has a limited area of occupancy estimated to be less than 500 $\mathrm{km}^{2}$ in a severely fragmented area and is currently only known from three localities. In additon, the continuing decline of its habitat due to the use as farm land which is from time to time subject to grazing and trampling by livestock could rapidly change the threat status. Therefore, the new species is considered Endangered: EN B1ab(iii), according to the IUCN red list criteria (IUCN 2015).

Etymology:- The specific epithet refers to the region where the species occur.

Additional specimens examined (paratypes):-PARAGUAY. Concepción: Aldea Pa'i Tavytera "Boquerón", S 22 52' 50,2", W 56 51' 18,7", 147 m, 5 March 2009, H. A. Keller, M. Dematteis \& M. Franco 6653 (CTES); 25 km N de Aldea Aborigen Boquerón, camino a Puentesiño, S 22³5'33", W 56²49'50", 5 March 2009, M. Dematteis, M. Franco \& H. A. Keller 3300 (CTES, FCQ).

Discussion:-The new species seems to be closely related to L. niederleinii but it differs in the margin and indumentum of leaves, number of phyllary series, trichome type of corollas and chromosome number. The most important differences between these species are summarized in Table 1.

TABLE 1. Diagnostic morphological characters of Lessingianthus concepcionis and L. niederleinii

\begin{tabular}{lll}
\hline & L. concepcionis & L. niederleinii \\
\hline Leaf size $(\mathrm{cm})$ & $7-8 \times 4.5-5$ & $5-10 \times 1.8-4.5$ \\
Leaf margin & denticulate and revolute & entire or briefly serrate, never revolute \\
Leaf beneath & tomentose & pubescent and glandular trichomes \\
Heads & sessile & sessile or briefly pedunculate \\
Phyllary series & $6-7$ & $4-5$ \\
Corolla trichomes & glandular & non-glandular and glandular \\
Cypsela size (mm) & $4-4.5$ & $3.5-4$ \\
Chromosome number & $2 \mathrm{n}=128$ & $2 \mathrm{n}=96$ \\
\hline
\end{tabular}

Lessingianthus concepcionis has glandular trichomes on corolla lobes (Fig. 2A), which were designated as "Type III" by Angulo \& Dematteis (2014a). These glandular trichomes occur on the dorsal side of corolla lobes and they have a uniseriate stalk and a unicellular head (Fig. 2B). Lessingianthus niederleinii has also glandular trichomes "Type III" but it has non-glandular Types I (unicellular, short) and II (multicellular, long, with a terminal cell longer than the other cells) (Angulo \& Dematteis 2014a).
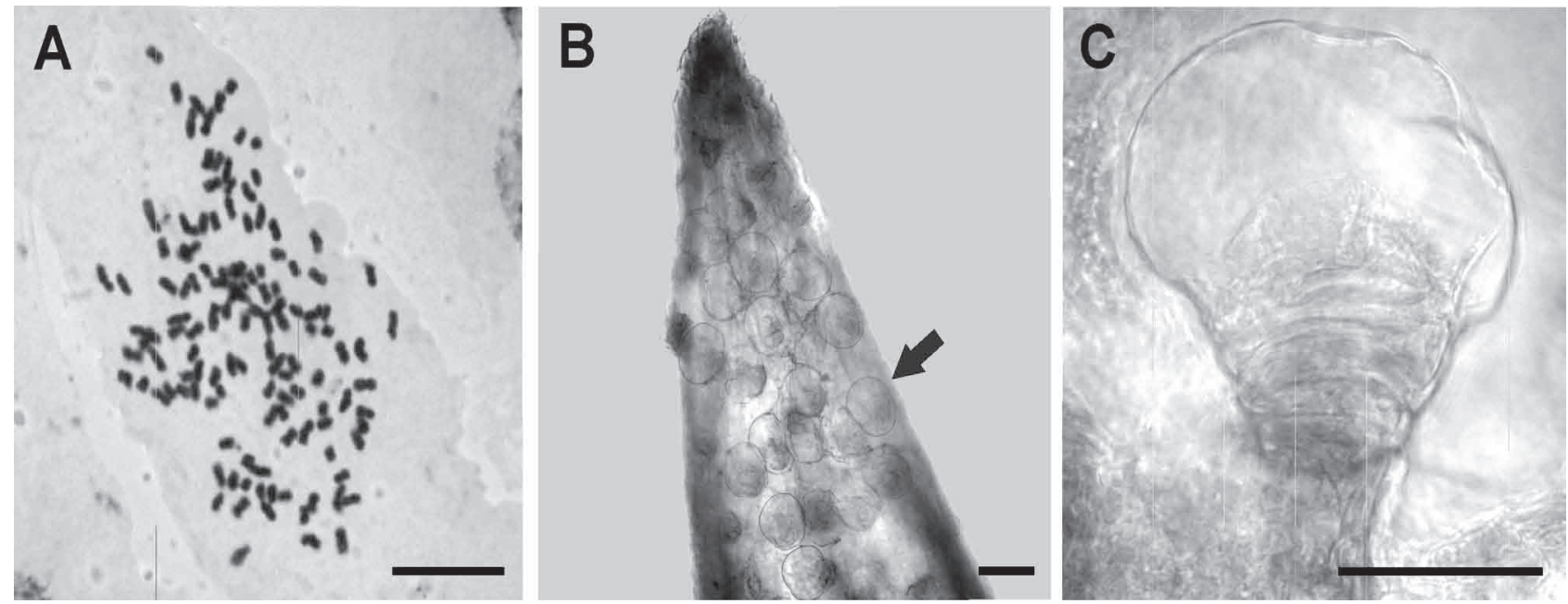

FIGURE 2. Somatic chromosomes and floral microcharacters of Lessingianthus concepcionis. A: Metaphase plate, $2 \mathrm{n}=128$. B: Corolla lobe tip with glandular trichomes (arrow). C: Detail of glandular trichome Type III. Scale bars= A-B: $10 \mu \mathrm{m}, \mathbf{C}: 50 \mu \mathrm{m}$.

The new taxon is an octoploid entity with $2 \mathrm{n}=8 \mathrm{x}=128$ (Fig. 2C), which constitutes the first chromosome count for the species and the third report of the octoploid ploidy level in the genus. On the other hand, L. niederleinii is hexaploid with $2 \mathrm{n}=6 \mathrm{x}=96$, as it has been supported by numerous chromosome counts in several populations from 
Paraguay and Argentina (Angulo \& Dematteis 2012a). Other octoploid taxa in Lessingianthus are L. scabrifoliatus (Hieronymus 1897: 677) Robinson (1994: 29) and L. hystricosus (Cabrera \& Dematteis 1999: 103) Dematteis (2010: 238). All counts carried out in several populations from Bolivia (L. scabrifoliatus) and Paraguay (L. hystricosus) showed 2n=128 (Dematteis 2002, Angulo \& Dematteis 2012a). However, the new species differs from L. scabrifoliatus in urceolate-campanulate involucre, 50-60 florets per head, mucronate apex of leaves, outer phyllaries with mucronate apex, glandular and non-glandular trichomes on corolla and cypsela. Regarding L. hystricosus, this taxon is only known to the central and eastern Paraguay and is distinguished from L. concepcionis by leaves with denticulate and undulate margins, 4-5 phyllary series, outer phyllaries linear and mucronate at apex, glandular and non-glandular trichomes on cypselas.

Lessingianthus concepcionis is locally used for the treatment of parasitic diseases based on the information obtained from interviews to several members of Aldea Pa'i Tavytera "Boquerón" (Concepción, Paraguay) carried out by collectors. This new taxon is locally known as "jagua pety" and their roots in decoction are used as an antiparasitic. Vernonanthura tweedieana (Baker 1873: 99) Robinson (1992: 74) is also known under the same common name as suggested by Portillo et al. (2005). These authors studied chemical constituents of roots in specimens of Paraguarí (Paraguay) and they identified a sesquiterpene as the antifungal agent. This chemical compound characterizes the Vernonieae tribe (Kelley \& Robinson 2009) and perhaps it would also be responsible for the antifungal activity in $L$. concepcionis.

\section{Acknowledgements}

We would especially like to thank the keepers and staff of the visited herbaria for their collaboration. The drawings of the species were prepared by Mirtha Liliana Gómez of the Instituto de Botánica del Nordeste. This work has been supported by grants from the Consejo Nacional de Investigaciones Científicas y Tecnológicas (CONICET) and the Secretaría General de Ciencia y Técnica of the Universidad Nacional del Nordeste (SGCyT-UNNE).

\section{References}

Anderson, L.E. (1954) Hoyer's solution as a rapid mounting medium for bryophytes. The Bryologist 57: 242-247.

http://dx.doi.org/10.1639/00072745(1954)57 [242:HSAARP]2.0.CO;2

Angulo, M.B. \& Dematteis, M. (2010) Pollen morphology of the South American genus Lessingianthus (Vernonieae, Asteraceae) and its taxonomic implications. Grana 49: 12-25. http://dx.doi.org/10.1080/00173130903435192

Angulo, M.B. \& Dematteis, M. (2012a) Cytotaxonomy of some species of the South American genus Lessingianthus (Asteraceae, Vernonieae). Plant Systematics and Evolution 298: 277-285. http://dx.doi.org/10.1007/s00606-011-0542-z

Angulo, M.B. \& Dematteis, M. (2012b) Taxonomy of the Lessingianthus saltensis (Vernonieae, Asteraceae) species complex. Annales Botanici Fennici 49: 239-247. http://dx.doi.org/10.5735/085.049.0404

Angulo, M.B. \& Dematteis, M. (2014a) Floral microcharacters in the genus Lessingianthus (Vernonieae, Asteraceae) and its taxonomic implications. Plant Systematics and Evolution 300: 1925-1940.

http://dx.doi.org/10.1007/s00606-014-1019-7

Angulo, M.B. \& Dematteis, M. (2014b) A new species and taxonomic novelties in the South American genus Lessingianthus (Vernonieae, Asteraceae). Phytotaxa 186 (4): 207-214.

http://dx.doi.org/10.11646/phytotaxa.186.4.4

Angulo, M.B. \& Dematteis, M. (2014c) Lessingianthus H. Rob. In: Zuloaga, F.O., Belgrano, M.J. \& Anton, A.M. (Eds.) Flora Argentina, Flora Vascular de la República Argentina Dicotyledoneae Asteraceae: Senecio a Vernonieae, vol. 7 (3). IBODA CONICET, Argentina, pp. 249-264.

Angulo, M.B. \& Dematteis, M. (2015) Karyotypes of some species of the genus Lessingianthus (Vernonieae, Asteraceae) and its taxonomic implications. Nordic Journal of Botany 33: 239-248.

http://dx.doi.org/10.1111/njb.00639

Angulo, M.B., Vega, A. \& Dematteis, M. (2012) Nuevas combinaciones en los géneros sudamericanos Lepidaploa y Lessingianthus 
(Vernonieae, Asteraceae). Gayana Botánica 69: 267-274.

http://dx.doi.org/10.4067/S0717-66432012000200006

Angulo, M.B., Sosa, M.M. \& Dematteis, M. (2015) Systematic significance of cypsela morphology in Lessingianthus (Vernonieae, Asteraceae). Australian Systematic Botany 28: 173-189.

http://dx.doi.org/10.1071/SB15022

Baker, J.G. (1873) Compositae. I. Vernoniaceae. In: Martius, C. (Ed.) Flora brasiliensis, vol. 6 (2). F.Fleischer, München \& Leipzig, pp. $1-179$.

Berchtold, F. von \& Presl, J. (1820) O prirozenosti Rostlin. Krala Wiljma Endersa, Prague.

Bowen, C.C. (1956) Freezing by liquid carbon dioxide in amking slides permanent. Stain Technology 31: 87-90. http://dx.doi.org/10.3109/10520295609113782

Cabrera, A.L. \& Dematteis, M. (1999) Novedades en el género Vernonia Schreb. (Compositae, Vernonieae) para la Flora del Paraguay. Candollea 54: 103-110.

Cassini, A.H.G. (1819) Suite du sixième mémoire sur la famille des Synanthérées, contenant les caractères des tribus. Journal de Physique, de Chimie, d'histoire Naturelle et des Arts 88: 189-204.

Dematteis, M. (1997) Números cromosómicos y cariotipos de algunas especies de Vernonia (Asteraceae). Boletín de la Sociedad Argentina de Botánica 33: 85-90. http://dx.doi.org/10.3109/10520296309061169

Dematteis, M. (2007) Taxonomic notes on the genus Chrysolaena (Vernonieae, Asteraceae), including a new species endemic of Paraguay. Annals Botanici Fennici 44: 56-64.

Dematteis, M. \& Angulo, M.B. (2010) Additions to the genus Lessingianthus (Asteraceae, Vernonieae) from South America. Rodriguésia 61: 233-241.

Dematteis, M. \& Angulo, M.B. (2012) New species of Lessingianthus (Asteraceae, Vernonieae) from Brazil and Paraguay. Blumea 57: $109-113$.

http://dx.doi.org/10.3767/000651912X653813

Dyer, A.F. (1963) The use of lacto-propionic orcein in rapid squash methods for chromosome preparations. Stain Technology 38: 85-90.

Hieronymus, G. (1897) Erster Beitrag zur Kenntnis der Siphonogamenflora der Argentina und Angrenzenden Länder, besonders von Uruguai, Paraguai, Brasilien und Bolivien. Botanische Jahrbürcher für Systematik, Pflanzengeschichte und Pflanzengeographie 22: $672-704$.

Humboldt, F.H. von \& Bonpland, A. (1809) Plantae Aequinoctiales: per Regnum Mexici, in Provinciis Caracarum et Nova Andalusiae, in Peruvianorum, Quitensium, Novae granatae Andibus, ad Orenoci, Fluvii Nigri, Fluminibus Amazonum ripas nascentes. F. Schoell, Paris, 234 pp. http://dx.doi.org/10.5962/bhl.title.16027

IUCN (2015) The IUCN red list of threatened species, version 2015.4. IUCN Red List Unit, Cambridge U.K. Available from: http://www. iucnredlist.org/ (accessed 23 February 2016)

Keeley, S.C. \& Robinson, H. (2009) Vernonieae. In: Funk, V.A., Susanna, A., Stuessy, T.F. \& Bayer, R.J. (Eds.) Systematics, evolution and biogeography of Compositae. International Association for Plant Taxonomy, Vienna, pp. 439-469.

King, R.M. \& Robinson, H. (1970) The new synantherology. Taxon 19: 6-11. http://dx.doi.org/10.2307/1217907

Oliveira, V.M., Forni-Martins, E.R. \& Semir, J. (2007) Cytotaxonomy of species of Vernonia, section Lepidaploa, group Axilliflorae (Asteraceae, Vernonieae). Botanical Journal of Linnean Society 154: 99-108. http://dx.doi.org/10.1111/j.1095-8339.2007.00633.x

Portillo, A., Vila, R., Freixa, B., Ferro, E., Parella, T., Casanova, J. \& Cañigueral, S. (2005) Antifungal sesquiterpene from the root of Vernonanthura tweedieana. Journal of Ethnopharmacology 97: 49-52. http://dx.doi.org/10.1016/j.jep.2004.09.052

Robinson, H. (1994) New combinations in American Vernonieae (Asteraceae). Phytologia 76: 27-29.

Robinson, H. (1988) Studies in the Lepidaploa complex (Vemonieae: Asteraceae), IV. The new genus Lessingianthus. Proceedings of the Biological Society of Washington 101: 929-951.

Robinson, H. (1999) Generic and subtribal classification of American Vernonieae. Smithsonian Contributions to Botany 89: 1-116. http://dx.doi.org/10.5479/si.0081024X.89

Ruas, P.M., Ruas, C.F., Vieira, A.O.S., Matzenbacher, N.I. \& Martins, N.S. (1991) Cytogenetics of genus Vernonia Schreber (Compositae). Cytologia 56: 239-247. http://dx.doi.org/10.1508/cytologia.56.239

Thiers, B. (2016) Index Herbariorum: A global directory of public herbaria and associated staff. New York Botanical Garden's Virtual Herbarium. Available from: http://sweetgum.nybg.org/science/ih/ (accessed 29 February 2016) 